\title{
INTERACTIVE STRATEGY TRAINER FOR ACTIVE READING AND THINKING (ISTART) FOR THE STUDENTS' READING COMPREHENSION
}

\author{
Hasnawati Latief, Khaerunnisa, Radiah Hamid \\ English Education Department, Universitas Muhammadiyah Makassar \\ Kaimuddin, \\ English Language Department, Universitas Negeri Makassar \\ hasnawatilatief@unismuh.ac.id
}

\begin{abstract}
This research aims to find the improvement of the students' reading in literal comprehension especially main idea and supporting idea in reading comprehension use of ISTART Strategy at Class VIII.5 of SMPN 2 Sungguminasa in the 2012/2013 Academic Year. The researcher used a Classroom Action Research (C.A.R). It was consisted of two cycles. In each cycle consisted of four meetings. The research subject was the students in class VIII.5; it consisted of 35 students with 18 men and 17 women. The researcher obtained the data by using reading test and observation sheet. The research findings indicates that using ISTART Strategy could improve the students' reading comprehension, from table 1 indicated that there was improvement the students' Main Idea from cycle I to cycle II, where as in cycle I the students' achievement main idea in reading was 6.65 , but after evaluation in cycle II the students' main idea in reading became 7.36. The other hand the students' supporting idea in reading was improved cycle I to cycle II, where as in cycle I the students' supporting idea in reading was 6.78 but after evaluation in cycle II the students' supporting idea in reading became 7.38. It means that the use ISTART Strategy could improve the students' reading comprehension at VIII.5 Class of the second year students of SMPN 2 Sungguminasa.
\end{abstract}

Keywords: Reading Comprehension, Interactive Strategy, Active Reading, Thinking Strategy

\section{INTRODUCTION}

In learning English, there are four skills we must comprehend. They are listening, speaking, reading, and writing. The four skills mentioned are divided into receptive and productive skills. Speaking and writing are productive skills, while listening and reading are receptive skills. Beside the four language skills above, reading is of great importance to student show mother tongue is not English, because they almost do not have opportunity to hear or to speak that 
language (Richard, 1998:35). Reading is also one ways to get information and it can improve people knowledge. By reading, people are able to know many things happen around them even they do not have to see it directly and through reading people can speak and write. Reading can make people become wide minded.

Comprehending English is a difficult thing for students if they are does not have basic knowledge, especially in comprehending reading text. According to (Nuttal, 1988:89) reading is a flexible for the students, because they can get information from the text they have read. Reading also is an active process identifying important ideas comparing.

Goodman (1973:6), states that reading is a psycholinguistic process by which the reader, a language user reconstructs, as best he can a message which has been encoded by a writer as a graphic display. In teaching reading, teacher should introduce other materials as an alternative to give various situations to student in classroom process. These materials can be a media; it can be create a comfortable atmosphere interest and to stimulate the students' motivation during the classroom process. In the other hand, most high motivation is needed to learn reading.

Related to the statements above, the researcher did observation that was done at Class VIII.5 of SMPN 2 Sungguminasa the researcher faces many problems in teaching learning English. The researcher found that the skill of students in reading is still low in literal comprehension, especially main idea and supporting idea. Where the researcher had done on observation for three days. The first day the researcher introduce an narrative text to the students, the second day the researcher asking question to the students about narrative text itself, and the last day the researcher did diagnostic test. The diagnostic text was asking the students to read the topic about narrative test. The result of diagnostic test proved that the students still low in reading comprehension. Most of the student's score it is about 4.12 but the standard curriculum 6.8.In this study, the researcher wants to solve this reading problem until the students have a good score between 70 .

Based on the explanation and observation result above, the researcher conducted a research entitle "Improving Students' Reading Comprehension 
through Interactive Strategy Trainer for Active Reading and Thinking (ISTART) Strategy at Class VIII.5 of SMPN 2 Sungguminasa.

\section{CONCEPT OF READING COMPREHENSION}

According Mikulecky and Jeffirs (1986:1), reading helps the students learn to think in the new language, builds a better vocabulary, and makes them more comfortable with writing English. As ability in reading increase, individual learn to adapt their reading strategies in matching with the purpose for reading and the limiting material. The reading activity reader must understand or comprehends what the reader read. This process calls cognitive process. Furthermore, Reiking and Scheiner as quoted by Kustaryo (1988:2) suggest that reading is an active cognitive process on interacting with print and monitoring comprehension to establish meaning. Reading is the process of putting the teachers in the contact communicating with ideas, reading could be defined as meaningful interpretation of writing symbols.

Comprehension always directed and controlled by the needs and purpose of the readers. Therefore, the readers cannot read with good comprehension if the subject of the text is one who does not know and has not real interest in it Hornsby (1995:25) State that reading comprehension is a term to identify those skills needed to understand and apply that information contained within written materials. Reading comprehension is a complex process the reader constructs meaning by interacting with text using his or her knowledge and experience the information that can be found in the text.

According Kustaryo in Miftayana I, (2010:11) Reading Comprehension is an active thinking process, which not only depends on comprehension is understa nding what has been read. But also the students' experience and prior knowledge comprehension involves understanding vocabulary. Seeing the relationship among words and concepts meaning judgment and evaluating.

Simanjuntak, et. al (1988:3) State reading is a process of putting the reader in contact and communication with ideas'. Kustaryo (1988:2) States that reading is stagnations recognition of various written symbols with exiting knowledge and 
comprehension of the information and ideas commutated while good comprehension is the act of understanding the meaning of printed or spoken language. Through the definitions we may understand that comprehension involves both oral and written language while reading is finding information from printed word only.

Sangkala, I., \& ul Haq, M. (2014) Innovating new technique in teaching reading is vital to address the nowadays students' need and problems in reading. Conventional technique such as lecturing has been inadequate to make the students understand and read well. More techniques are needed by the teachers to vary their teaching technique or using multimedia.

Reading Comprehension is the purpose of understanding and constructing meaning from a piece of text. Connected text is any written materials involving multiple words. That forms coherent thoughts, phrases, sentences, paragraphs and so on are examples of connected text can be read with comprehension.

\section{Levels of Comprehension}

Burns in Rauf (2012: 20) devises that reading comprehension skills is divide into four categories in the following bellow:

\section{1) Literal Comprehension}

Literal reading is the skills or getting the primary, direct literal meaning of a word, ideas, and a sentence in context. It is a little thinking of reasoning for it merely skill of finding what the author says some specific reading skills at the literal level of comprehension are: understanding of main idea and supporting idea.

a) Main Ideas

The main idea of a passage or reading is the central though or message. In contrast to the term topic, this refers to the subject under discussion; the term main idea refers to the point or though being expressed. Once you can find the topic, you are ready to find the main idea. The main idea is the point of the paragraph it is the most important thought about the topic. The author can locate the main idea in different 
place within the paragraph. The main idea is usually the first sentence of paragraph. The author gives supporting information first and then makes the point in the last sentence.

b) Supporting Idea

Supporting idea is statement are support your topic or theme. You support your main idea by explaining it, describing it, defining it, or otherwise giving information about it. You will usually need to actually look up or search this information! When you are writing an essay or report, each paragraph after the introduction should discuss one supporting idea. Depending on how many paragraph you want to include, you can have any number of supporting idea. This detail are than repeated or rephrased in your including paragraph, to restate the fact that they support your main idea. Give more information about the topic and or details or information that backs up a sentence.

2) Interpretative Reading

The next type of comprehension is interpretative reading. Interpretative Reading is based on a literal understanding in the text; students must use information from various part of the text and combine them for additional understanding. The students have to put together two piece of information that is from different part of the text.

Interpretative reading involves thinking skills in which readers identify ideas and meaning that are not stated explicitly in the written text, so interpretative reading is higher that literal reading, in which readers may make generalization, determine cause and effect, identify motives and may make comparisons. In cause effect is an action reaction combination the cause is that thing which makes something else happens. The effect is what it is that happens as a result of the cause so there is always a relationship between cause and effect

3) Critical Reading

Critical Reading is the ability to evaluate the credibility of piece of writing. All writers have a purpose when they write, and usually a writer will 
choose or emphasize facts and details which support his or her purpose, ignore facts which do not support his writing. As a good reader, we need to be aware of that. Critical evaluation occurs only after our students have understood the ideas and information that the writer has presented, the students can be tested on the following skills:

a) The ability to differentiate between facts and opinion

b) The ability to recognize persuasive statements

c) The ability to judge the accuracy of the information given in the text.

\section{The Concept of ISTART Strategy}

Interactive Strategy Trainer for Active Reading and Thinking (ISTART) Strategy is a picture sequence based tutoring system designed to improve student' reading comprehension by teaching self -explanation (McNamara, et al, 2004:7). Unfortunately, many students have difficulty understanding what they read, particularly in challenging textbooks such as those used in science course (Snow, 2002:2).

Some of these difficulties stem from students' lack of knowledge about and failure to use metacognitive comprehension strategies while reading their course material (Cottrell \& McNamara, 2002:9). Interactive Strategy Trainer for Active Reading and thinking (ISTART) Strategy, which is an interactive reading strategy trainer that utilizes picture sequence to provide reading strategy instruction.

All of the students then self-explained a text about heart disease and answered text-based and bridging-inference questions.

From a reading perspective, there are two general classes of reading deficits:

1) Decoding problems, such that the individual is not able to convert the written word to its phonological or semantic referent.

2) Comprehension problems, such that the reader is unable to integrate the words and sentences into a coherent understanding of the text. 
This study focuses on the latter problem students who can read the words, but who do not fully comprehend what they read. The purpose of this study is to examine the effectiveness of an automated reading strategy intervention called Interactive Strategy Trainer for Active Reading and Thinking (ISTART) Strategy; (McNamara, et al, and 2004:12) in helping adolescent readers learn reading strategies, and improve their comprehension of science text.

\section{The Step of Implementation}

According to (McNamara, et al: 2004:78) there are five steps considered important in the implementation of ISTART Strategy:

1) the trainee is provided with instruction concerning self-explanation and reading strategies

2) The researcher show that picture sequence reading to the student in the form of reading text

3) The researcher give the students chance to read the text given in pairs and monitoring students error in reading

4) The researcher provided instruction concerning self-explanation and reading strategy.

5) Called practice and the students make inferences about the material.

The goal is to help the trainee acquire the skills necessary to integrate prior text and prior knowledge with the sentence content.

\section{ISTART Strategy in Reading Text}

Thus, in ISTART Strategy, the students are taught reading strategies to improve their ability to self-explain. In turn, the process of self-explanation helps the students learn how to use the reading more effectively.

According to (e.g., Kintsch, 1998:8). The ISTART Strategy coaches student in five reading strategies:

1) Comprehension monitoring, enables the reader to recognize a failure of understanding and it is this recognition that triggers the use of additional active reading. 
2) Paraphrasing essentially helps students remember the surface structure of the text by transforming it into more familiar ideas.

3) Making bridging inferences improves comprehension by linking the current sentence to the material previously covered in the text.

4) Prediction, Students may also use prediction to anticipate the content of subsequent text, either by guessing what is coming next or by reminding themselves to watch out for some particular item that will aid comprehension.

5) Elaboration, readers may associate the current sentence with their own related prior knowledge using a strategy Comprehension monitoring. Elaboration essentially ensures that the information in the text is linked to information that reader already knows.

\section{Post Training ISTART Strategy in Reading Text}

After the training phase, the participants ISTART Strategy (without being provided feedback), which is described the various causes and forms of common heart diseases. The passage is an excerpt from the low-cohesion version of the heart-disease text used in McNamara, et al. (1999:2).

Students' comprehension of the text is assessed with nine open-ended comprehension questions. Five of the questions are bridging inference questions, and four questions are text-based. Bridging inference questions require the reader to bridge information across two or more sentences to form a correct answer.

In contrast, the text-based questions can be correctly answered using information from a single sentence. An example of a bridging-inference question is "Describe how a coronary thrombosis affects the heart"; while an example of a text-based question is "What causes rheumatic fever?" The answer to the former bridging inference question required four sentences to answer.

The underlying assumption of ISTART Strategy are that instruction to use more effective reading strategy will improve readers' ability to read the text and in turn, that externalization of the reading strategy with the ISTART Strategy. 


\section{RESEARCH METHODOLOGY}

The method that used a classroom action research (C.A.R). It conducted through two cycles to observe the students' ability to read English through Interactive Strategy Trainer for Active Reading and Thinking (ISTAR). It consists of planning, action, observation and reflection. The classroom action research is carry out by researcher and English teacher as collaborator. The following are the variables of the research:

Remembering that variable is one of the very important elements of research, the research used two kinds include of variable. Those variables can be divided into two variables. Those are dependent variable and independent variable that is the variable that influence the other variable.

1. Independent Variable

Independent variable of the research is the use of ISTART Strategy in teaching reading comprehension.

2. Dependent Variable

Dependent variable is increasing the students' reading in literal comprehension. The Indicators are:

1. Main idea in narrative text

2. Supporting idea in narrative text.

The subject of this research is the students at class VIII.5of SMPN 2 Sungguminasa in 2012/2013 Academic Year. The Instrument used, there are:

1. Observation

Observation that used to watch out the situation of teaching and learning process which covers the method applies by a teacher in the class. 
Table 1. Scoring Rubric of Students' Activeness

\begin{tabular}{|c|c|c|c|}
\hline No & $\begin{array}{c}\text { The students' Active } \\
\text { Participation }\end{array}$ & Score & Indicator \\
\hline 1 & Very Active & 4 & $\begin{array}{l}\text { Students' respond to the material very } \\
\text { active }\end{array}$ \\
\hline 2 & Active & 3 & Students' respond to the material actively \\
\hline 3 & Fairly active & 2 & $\begin{array}{l}\text { Students' respond to the material just } \\
\text { once or twice. }\end{array}$ \\
\hline 4 & Not active & 1 & $\begin{array}{l}\text { Students just sit down during the activity } \\
\text { without doing something. }\end{array}$ \\
\hline
\end{tabular}

2. Reading Test

Reading test aims to test the students' basic competence in comprehending a reading text.

Table 2. Scoring Rubric of Reading Comprehension

\begin{tabular}{|c|l|c|}
\hline No. & \multicolumn{1}{|c|}{ Criteria } & Score \\
\hline 1. & The meaning and structure are correct & 4 \\
\hline 2. & $\begin{array}{l}\text { The meaning is correct and some errors of } \\
\text { structure }\end{array}$ & 3 \\
\hline 3. & Some errors of meaning and structure & 2 \\
\hline 4. & The meaning and structure are incorrect & 1 \\
\hline 5. & No answer & 0 \\
\hline
\end{tabular}

Depdikbud (2005:27)

3. The Students' Reading in Literal Comprehension:

Table 3. Scoring Rubric of Main Idea

\begin{tabular}{|c|l|c|}
\hline No. & \multicolumn{1}{|c|}{ Criteria } & Score \\
\hline 1. & $\begin{array}{l}\text { The answer includes a clear generalization that states or } \\
\text { implies the main idea }\end{array}$ & 4 \\
\hline 2. & $\begin{array}{l}\text { The answer states or implies the main idea from the } \\
\text { story }\end{array}$ & 3 \\
\hline 3. & $\begin{array}{l}\text { Indicator inaccurate or incomplete understanding of } \\
\text { main idea }\end{array}$ & 2 \\
\hline 4. & $\begin{array}{l}\text { The answer include minimal or no understanding of } \\
\text { main idea }\end{array}$ & 1 \\
\hline 5. & No answer & 0 \\
\hline
\end{tabular}

Harmer in Rauf. (2012: 32) 
In collecting the data, the researcher that used two instruments i.e. observation sheet, and reading test. The type of data collection consist of quantitative data in which the instrument used test and qualitative data in which the instrument used observation and questions.

The way to take data as follows:

1. Observation sheet; the observer was observed the students' activeness and presence in the teaching and learning process by using observation sheet.

2. The Researcher was given reading test to the students in order to read the text to their improvement after taking actions in cycles.

\section{DISSUSION}

The results of the findings indicate that teaching reading comprehension through ISTART Strategy can improve the students' achievement in literal comprehension. Further interpretations of the data analysis are given below:

\section{The Students' Improving in Literal Reading Comprehension}

The improvement of the students' literal reading comprehension, which focused on main ideas and supporting idea as indicators at Class VIII.5 of SMPN 2 Sungguminasa as result of the students' assessment of cycle I and cycle II, is described as follows:

Table 4. The Students' Improvement Main idea and supporting Idea

\begin{tabular}{|c|l|c|c|c|c|c|}
\hline \multirow{2}{*}{ No. } & Indicators & \multicolumn{3}{|c|}{ Score } & Improvement(\%) \\
\cline { 3 - 7 } & & D-T & Cycle I & Cycle II & $\begin{array}{c}\text { DT - } \\
\text { CI }\end{array}$ & $\begin{array}{c}\text { DT- } \\
\text { CII }\end{array}$ \\
\hline 1. & Main Ideas & 4.28 & $\mathbf{6 . 6 5}$ & $\mathbf{7 . 3 6}$ & $\mathbf{2 3 . 7 \%}$ & $\mathbf{3 0 . 8 \%}$ \\
\hline 2. & $\begin{array}{l}\text { Supporting } \\
\text { Idea }\end{array}$ & $\mathbf{4 . 4 2}$ & $\mathbf{6 . 7 8}$ & $\mathbf{7 . 3 8}$ & $\mathbf{2 3 . 6 \%}$ & $\mathbf{2 9 . 6 \%}$ \\
\hline & $\sum \mathrm{X}$ & $\mathbf{8 . 7}$ & $\mathbf{1 3 . 4 3}$ & $\mathbf{1 4 . 7 4}$ & $\mathbf{4 7 . 3 \%}$ & $\mathbf{6 0 . 4 \%}$ \\
\hline \multicolumn{2}{|c|}{$\bar{X}$} & $\mathbf{4 . 3 5}$ & $\mathbf{6 . 7 1}$ & $\mathbf{7 . 3 7}$ & $\begin{array}{c}\mathbf{2 3 . 6 5} \\
\mathbf{\%}\end{array}$ & $\mathbf{3 0 . 2 \%}$ \\
\hline
\end{tabular}

Based on the table above, it indicates that there was an improvement of the students reading in literal comprehension which consists of main idea and supporting idea in each test. The mean score of the students in diagnostic test was 
4.35, but after applied ISTART Strategy in the first cycle as a strategy to improve the students reading in literal comprehension, the mean score of the students increased to 6.71 or $23.65 \%$ higher than the last test. There was also significant improvement of the mean score at the first cycle test to the second cycle test. It was 6.71 to 7.37 or $6.6 \%$ higher than the last test. It means that, there was $30.2 \%$ improvement from diagnostic test to cycle II.

As clearer data of the students' reading in literal comprehension, the researcher also presented the data by using chart; the data could be seen in this following chart,

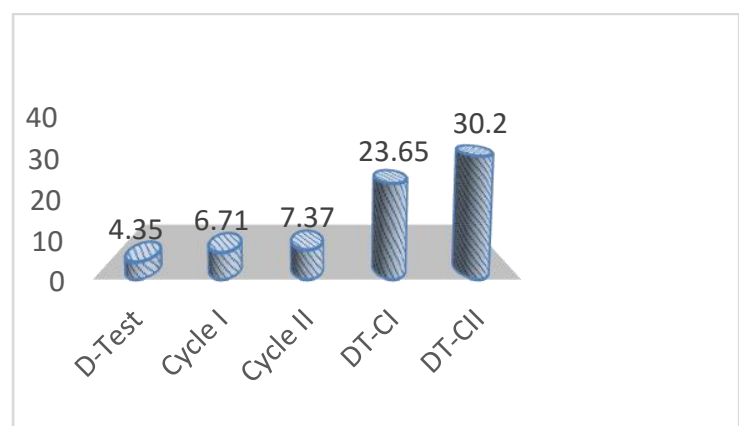

Chart 1. The Chart of Indicators of Literal Reading in Cycle I and Cycle II

The chart above indicates that the score of D-test $(4.35 \%)$ is fewer than score of cycle I (6.71\%). It means that the students' gain improvement, even though it is still classified as fair. This also means that the target in cycle I has not achieved yet. So, the researcher has decided to organize cycle II with several recorrecting activities and the result of cycle II (7.37\%) which is greater than D-Test and cycle I. It is classified as good. This means that there is improvement of the students' literal comprehension (30.2\%) and the target can be achieved. Finally, the ISTART Strategy is effective for students.

\section{The Percentage of the Students' Literal Comprehension in Reading Comprehension}

The following table showed the percentage of student's literal reading comprehension especially main idea in D-Test without the application of ISTAR Strategy, cycle I and cycle II with application of ISTART Strategy. 
Table 5. The Criteria and Percentage of the Students' Reading in Literal Comprehension

\begin{tabular}{|c|c|c|c|c|c|c|c|}
\hline \multirow[t]{3}{*}{ Classification } & \multirow[t]{3}{*}{ Score } & \multirow{2}{*}{\multicolumn{2}{|c|}{$\begin{array}{c}\begin{array}{c}\text { Non ISTART } \\
\text { Strategy }\end{array} \\
\text { D-Test }\end{array}$}} & \multicolumn{4}{|c|}{$\begin{array}{l}\text { The Application of } \\
\text { ISTART Strategy }\end{array}$} \\
\hline & & & & \multicolumn{2}{|c|}{ Cycle I } & \multicolumn{2}{|c|}{ Cycle II } \\
\hline & & $\mathrm{F}$ & $\mathrm{P}(\%)$ & $\mathrm{F}$ & $\mathrm{P}(\%)$ & $\mathrm{F}$ & $\mathrm{P}(\%)$ \\
\hline Excellent & $9.6-10$ & 0 & 0 & 0 & 0 & 0 & 0 \\
\hline Very good & $8.6-9.5$ & 0 & 0 & 0 & 0 & 0 & 0 \\
\hline Good & $7.6-8.5$ & 0 & 0 & 0 & 0 & 11 & $31.43 \%$ \\
\hline Fairly good & $6.6-7.5$ & 0 & 0 & 25 & $71.43 \%$ & 24 & $68.57 \%$ \\
\hline fairly & $5.6-6.5$ & 0 & 0 & 8 & $22.86 \%$ & 0 & 0 \\
\hline poor & $3.6-5.5$ & 31 & $88.57 \%$ & 2 & $5.71 \%$ & 0 & 0 \\
\hline Very poor & $0-3.5$ & 4 & $11.43 \%$ & 0 & 0 & 0 & 0 \\
\hline \multicolumn{2}{|c|}{ Total } & 35 & $100 \%$ & 35 & $100 \%$ & 35 & $100 \%$ \\
\hline
\end{tabular}

The table above showed that the percentage of the students' reading in literal comprehension in Diagnostic test indicated that 4 students (11.43\%) got very poor, 31 students $(88.57 \%)$ got poor and none for the other classification.

After taking action in cycle I, there were 2 students (5.71\%) got poor, 8 students (22.86\%) got fairly, and 25students (71.43\%) got fairly good and none for the other classification. Continued to the next cycle, it was cycle II there was24 students (68.57\%) got fairly good, and 11 students $(31.43 \%)$ got good and none for the other classification.

The researcher also prepared the data in chart to know the percentage of the students' reading in literal comprehension clearly, the data presented in this following chart:

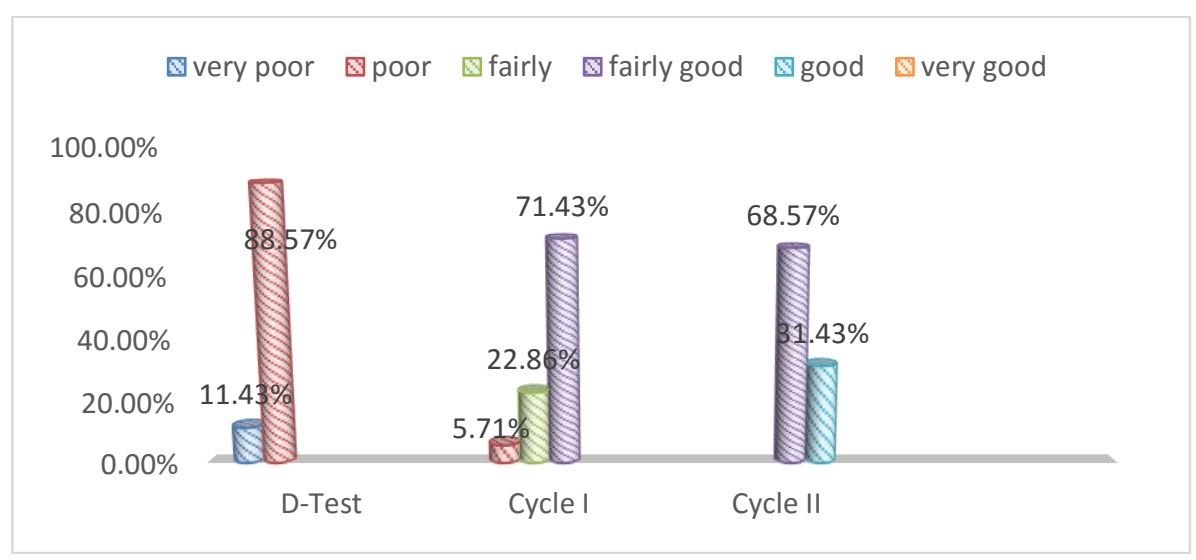

Chart 2. Students' Reading Comprehension Improvement 
The chart above showed that the percentage of the students' reading comprehension in cycle II was highest than Diagnostic test and cycle I where the students' reading comprehension percentage in cycle II was $31.43 \%$ categorized as good, and $68.57 \%$ categorized as fairly good. While the percentage of the students reading comprehension in cycle I was $71.43 \%$ categorized as fairly good, $22.86 \%$ categorized as fairly and $5.71 \%$ categorized as poor. But, the lowest percentage was showed in diagnostic test where $11.43 \%$ categorized as very poor, $88.57 \%$ categorized as poor.

After evaluated all of the result of the students reading in literal comprehension in diagnostic test, cycle I and cycle II. It was clearly that the students reading in literal comprehension were improved by using this strategy. In this section, the researcher also presented the data of the students reading comprehension improvement commonly from the first cycle to the second cycle. It was aimed to see the differences of the result in each cycle, weather the students reading in literal comprehension improved or not by using ISTART Strategy the data could be seen in this following table:

Table 6. The Student' Reading Comprehension

\begin{tabular}{|c|c|c|c|c|}
\hline \multirow{2}{*}{ No. } & Variable & Cycle I & Cycle II & Improvement \\
\cline { 3 - 4 } & & Score & Score & \\
\hline 1. & Literal & 6.71 & 7.37 & $\mathbf{6 . 6 \%}$ \\
\hline \multicolumn{2}{|c|}{$\bar{X}$} & 6.71 & 7.37 & \\
\hline
\end{tabular}

Based on the table above, it indicates that the mean score of the students reading comprehension in the first cycle to the second cycle was improved. In the first cycle, the score 6.71 and the next cycle the mean score was 7.37. It means that the standard minimal achievement in the school is reached. Where the standard minimal achievement is 6.8 and the students' achievement in the last cycle was 7.37.

For the clearer data of the standard reading comprehension improvement, the researcher presented the data into a chart; the data could be seen in this following chart, 


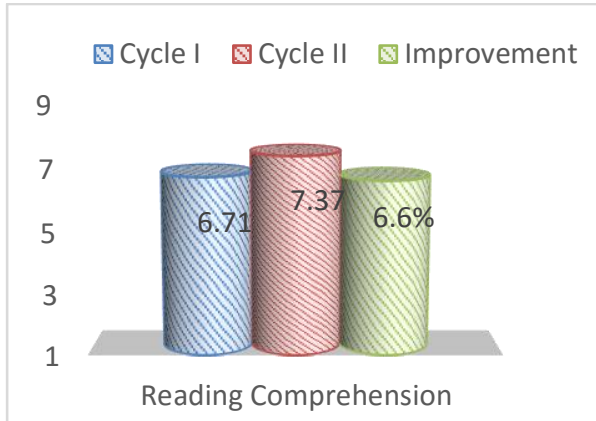

Chart 3. The students reading comprehension achievements during the cycles

The chart above clearly shows that there was an improvement of the students reading comprehension from the first cycle to the second cycle. In the first cycle, the mean score of the students reading was 6.71. After evaluated the weakness in the first cycle, finally in the second cycle the students could reached 7.37. It is $6.6 \%$ higher than the first cycle.

\section{The Result of Observation for Students Activeness}

During the researcher for eight meetings, the researcher had made an observation sheet about the students' activeness during the learning process at the class. The data of the students' activeness could be seen in this following table,

Table 7. The Students’ Activeness

\begin{tabular}{|l|l|c|c|c|c|}
\hline \multirow{2}{*}{ No } & \multirow{2}{*}{ Cycle } & \multicolumn{4}{|c|}{ Meetings (\%) } \\
\cline { 3 - 6 } & & $1^{\text {st }}$ & $2^{\text {nd }}$ & $3^{\text {rd }}$ & $4^{\text {th }}$ \\
\hline 1 & Cycle 1 & $44.28 \%$ & $51.42 \%$ & $56.42 \%$ & $64.28 \%$ \\
\hline 2 & Cycle 2 & $68.57 \%$ & $72.85 \%$ & $75.71 \%$ & $80.71 \%$ \\
\hline
\end{tabular}

The result above is formulated based on the technique of the data analysis. Based on the table above, it indicates that the students' activeness was improved in each meeting. In the first cycle, the percentage of the students' activeness was low. It happened because, there were students still felt embarrass to perform their ability. But after the researcher motivated them and guided them, several students became more confidence to show their ability. It could be seen from the increased percentage in the second cycle. The percentage of the students' activeness is very contrast, where the highest percentage in the first cycle only until $64 \%$ but in the second cycle, the highest percentage was $80.71 \%$. In shows that the activeness of the students' are improved as much as the students' reading comprehension. 
To see the clearer differences between each meeting, the researcher had prepared the chart of the students' activeness. The data could be seen in this following chart.

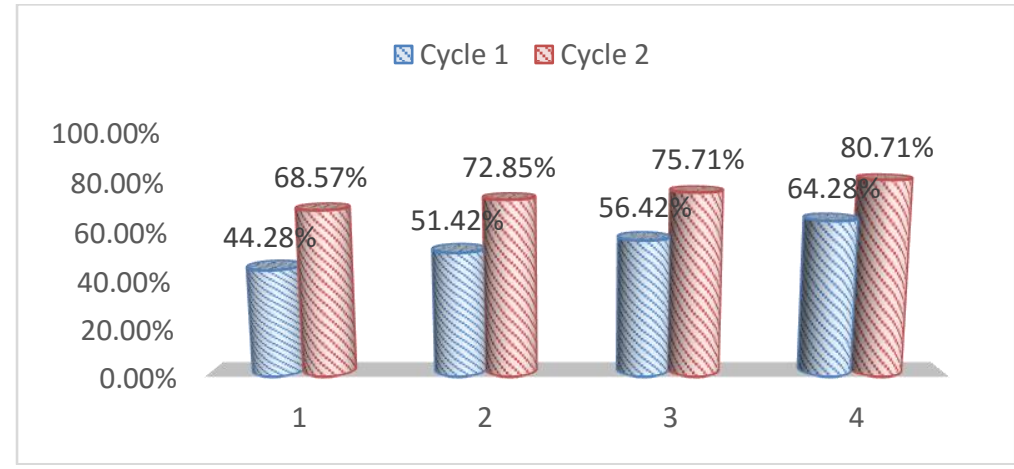

Chart 4. The Students' Activeness

The table above is seen like a ladder, where the percentage of the students' activeness improved gradually. The short tubes are showed in the first cycle, it means that the students' activeness in this cycle was still low because the percentage of the students' participation during this cycle under $56 \%$. It is indicated, there was only a half of students active in the class followed the learning process.

After the researcher sees the result in the first cycle, the researcher evaluated the weakness and tried to make the better preparation in the next cycle, not only from the strategies in teaching at the class but also the way to motivate the students. After doing the evaluation, finally the percentage of the students' activeness increased.

The research finding indicated that the students' reading comprehension through ISTART Strategy showed the improvement of the students' reading comprehension, from the improvement showed the process from the cycle I to cycle II. The process covered about their literal comprehension from fair to fair good.

The researcher has change the activity more interesting in cycle II so that students could show the improvement, in the first cycle the researcher gave less motivation and explanation about ISTART Strategy to students, but in cycle II the students really enjoyed the ISTART Strategy because the researcher gave more 
motivation and explanation intensively. At the beginning, the students were hard to understand the text reading and lazy, their literal comprehension, the researcher also gave explanation clearly what to do for easy understanding in reading comprehension. As the result the students became active and familiar with the condition in learning process.

1. The first meeting in cycle $I$, the researcher checked students name and explained what ISTART Strategy and then the researcher gave the picture material every students to make self-explanation about the topic. After the students self-explanation the researcher gave the text about the topic of the picture and the title of the material is Maling Kundang. Then researcher asks the students to read the material. After the students read the text the researcher asks to answer the question base on the text.

2. The second meeting in cycle I, the researcher checked their name. After that, the researcher gave the picture material every student to make selfexplanation about the topic. After the students self-explanation the researcher gave the text about the topic of the picture and the title of the material is the ugly duckling. The researcher explanation about narrative text and types of narrative text, the researcher asked students' what kinds of the text? And also researcher asked students whether they knew about the lion and the mouse or had they ever heard the story about it. This way could stimulate the students' knowledge into reading text. Next researcher asked students to read the text about the material by the researcher, after that the students will get guides about the material and researcher asked students to read the material and to found out the main idea and supporting idea base on the text. After that the researcher asked students answer the question.

3. The third meeting in cycle I, the researcher checked their name. After that the researcher explanation about generic structure of narrative text and how to found main idea and supporting idea in at text. And then the researcher gave students the title about Smart Monkey and Dull Crocodile. The process of this meeting is same with the first and the 
second meeting, but the researcher found that the students' were difficult to found the main idea and supporting idea of the text

4. The fourth meeting in cycle I, the researcher checked their name in this meeting the researcher gave story in the title Smartest Parrot. This story is funny so students' more interesting and the students looked enjoying in learning process.

The result after applying action of ISTART Strategy showed the students' score was improving. This score was taken from students reading test and calculating through ISTART Strategy in mean score and data analysis after that the researcher used the score of test to find out the students improvement but the mean score still low was 6.71 so the researcher decide to continue I n cycle II.

5. The fifth meeting in cycle II. In this meeting the researcher still used ISTART and gave the students in the title The Legend of Tangkuban Perahu. Each student read the text and work individually, the researcher gave addition frame work to the students that must be write the main idea and supporting idea. The students enjoyed to learning process, because they got interesting story.

6. The sixth meeting in cycle II, the researcher gave the students title about The Lion and the Mouse. Same the fifth meeting, the students answer the question to found the main idea and supporting idea in the text.

7. The seventh meeting in cycle II, the researcher gave the students title about The Cap Seller and the Monkeys. The process of this meeting is still same. The students looked enjoy to read the text and easily to understand the text and the students more good to do their exercise.

8. The eight meeting in cycle II, this meeting is become the last meeting in cycle II and the process of teaching and learning process same as the seventh meeting the title of story in this meeting is the Prince and his Best Friend. In this meeting the students were very active, enthusiast and enjoy in learning process. They could answer the question about main idea and supporting idea in narrative text. 
The result of cycle II in using ISTART Strategy showed that the students' improve. The score was taken from students' reading test and calculating by using in main score in data analysis. And then the researcher used the mean score of cycle I and cycle II to find out the student's improvement percentage this students improvement in using ISTART Strategy improve significantly from cycle I to cycle II, the mean score improve from6.71to 7.37

As a result based on the finding above shown that after calculating the students score it showed the students mean score in cycle I and cycle II. It means that the use ISTART Strategy can improve the student reading comprehension.

In this part, discussed deals with the literal of findings derived from the result of findings about the observation result of the students reading comprehension in term of literal comprehension dealing with main idea and supporting idea.

The research had done in two cycle and cycles consisted for meeting. The research found in the cycle I, that although all of students knows how to read but most of them difficult to understand what they have read.

Based on the unsuccessful teaching revised the lesson plan. Where when the researcher explained about the step of ISTART Strategy should explain more clearly, if needed gave chance to the students to ask about the material. Besides that, the researcher had to give better guidance for the student in reading text.

\section{CONCLUSION}

Based on the research findings and discussion in the previous chapter, the researcher comes to the following conclusions.

1. The use of ISTART Strategy can improve the students reading comprehension especially in literal comprehension (main idea and supporting idea) at Class VIII.5 of SMPN 2 Sungguminasa. The findings indicate that the mean score of test for cycle II is higher than the mean score of test for cycle I. in the cycle I, the score was 6.71 and the next cycle the mean score was 7.37. It means that the standard minimal achievement is 6.8 and the students' achievement in the 
last cycle was 7.37. It is higher that the cycle I. There was $6.6 \%$ improvement from cycle I to cycle II.

2. The use ISTAR Strategy can improve the students' reading activeness at Class VIII.5 of SMPN 2 Sungguminasa.

\section{BIBLIOGRAPHY}

Abbot, Naya, Seiji, Graham. 1982. Cooperation. Manila: Asian Development Bank.

Alley, W.B. 1994. The IEA Study of Literacy. Achievement and Instruction in Thirty Two School System. USA: Pergamon.

Anderson, J. Durton H. Berry and Millicent. 1985. Efficient Reading: A Practical Guide, Sidney: MC. Grew-Hill Book Company.

Boonthum Chutima. 2004. Eliciting Self Explanations Improves Understanding. Cognitive Science.

Cottrell, K. and McNamara, D. S. 2002. Cognitive Precursors to Science Comprehension. NJ: Erlbaum.

Crystal, David, Davy D. 1980:Stylistic Analysis. The Edinburgh Course in Applied Linguistic Volume 1: Reading for Applied Linguistics.

Davies and Whitney, 1983. Reading and Comprehension. Delhi: Aurora Offset Press.

Depdikbud. 1985. Petunjuk Pelaksanaan Proses Belajar Mengajar dan Petunjuk Pelaksanaan Penilaian. Jakarta: Departemen Pendidikan dan Kebudayaan.

Depdikbud.2005. GBPP Pengajaran Bahasa Inggris SLTP. Jakarta: Direktorat Jenderal Pendidikan Pusat.

Frey Edward, 1981: Teaching Faster Reading. A Manual Cambridge: Cambridge University Press. 
Goodman 1988: Ten Steps to Building College Reading Skills. Townsend: Townsend Press.

Grant Guymon, Ronald Edward, Harrison. (1980). Structured Tutoring. Englewood Cliffs: Educational Technology Publications.

Heidi and Byrness, (1998). Phonology, Reading and Dyslexia. Insights from Connectionist Models. Psychological Review.

Hornsby, 1995: Oxford Advanced Learners Dictionary of Current English. Britain Fifth Edition Oxfords: University Press.

Kintsch. W. (1998). Comprehension: A paradigm for Cognition. New York: Cambridge University Press.

Kustaryo, S. (1988). Reading Technique for College Students'. Jakarta: P2LPTK

Lewin, G. (1948). Games for Children. Oxford: Oxford University Press.

McNamara, D. S., Levinstein, I. B., \& Bonthum, C. (2004). iSTART: Interactive strategy trainer for Active Reading and Thinking. Behavioral Research Methods, Instruments, and Computers.

McNamara, D. S., 2001. Reading Both High Coherence and Low Coherence Text: Effects of Text Sequence and Prior- Knowledge.

McNamara, D. S., \& Scott, J. L. (1999). Training Reading Strategies.

Mikulecky, B. S. and L. Jeffries. 1986. Reading Power. Boston: Addison Wesley Publishing Company.

Nunan.1995.Language Teaching Methodology. New York .PHOENIX ELT.

Nuttal, N. 1988. Teaching Reading Skill in Foreign Language. Oxford: Heinemann International Publishing Company. 
Richard C. 1998.Becoming a Nation of Readers. Washington, DC: US Department of Education, the National Institute of Education.

Sangkala, I., \& ul Haq, M. (2014). Wondershare Quiz Creator Software Improves Students' Reading Comprehension. JKIP, 1(2), 128-135. Retrieved from https://ojs.fkip.unismuh.ac.id/index.php/jkip/article/view/41

Sudjana, 1990. Metode Statistika, Bndung: PT. Gramedia.

Simanjuntak, Groria, Editihia. 1988. Developing Reading Skill for EFL Students: Jakarta.

Snow, C. (2002). Reading for Understanding: Toward an R \& D program in Reading Comprehension. Santa Monica, CA: RAND.

Sukardi. 2008. Metodologi Penelitian Tindakan. Jakarta: Bumi Aksara.

Woryodijoyo S. 1989. Membaca: Strategy Pengantar dan Tekniknya. Jakarta: Depdikbud. 